\title{
Time to drop the language of 'consensus'
}

\author{
Leigh Turner
}

There is considerable emphasis in the bioethics literature on seeking consensus, encouraging democratic deliberation whereby reasonable people are supposed to achieve common understandings through reason giving and argumentation, and insisting that 'society' needs time to reach decisions about complex biotechnologies ${ }^{1,2}$. I suggest that understanding and consensus commonly can only be partial. As a consequence, placing the bar for public moral deliberation too high means that policy formation is endlessly deferred.

The language of consensus emphasizes uniformity, shared values and common standards. Society, one often hears, needs time to resolve complex matters of ethics and policy. This emphasis on common norms and the emergence of a social consensus sets the bar far too high for ethical analysis and regulation of biomedical technologies. Whether we are referring to gene therapy, genetically modified organisms, embryonic stem (ES) cell research, pharmacogenomics, therapeutic cloning or xenotransplantation, biomedical technologies emerge within complex social orders.

But we do not live in small villages where all individuals are guided by the same religious ethic or cultural norms; rather, contemporary nations are typically multicultural, multifaith and multilingual. A quick scan of any city telephone directory in Europe or North America will reveal the presence of churches, shrines, synagogues, mosques and temples. Within one religion-Judaism, for example-one finds Orthodox, Conservative and Reform leaders and communities. Even within these clusterings, one finds sharp theological disagreements about the ethical status of biomedical technologies.

Leigh Turner is in the Biomedical Ethics Unit, Department of Social Studies of Medicine, Faculty of Medicine, McGill University, 3647 Peel Street, Montreal, Quebec H3A 1X1, Canada, and clinical ethicist at Montreal General Hospital, 1650 Cedar Avenue, Montreal, Quebec H3G 1A4, Canada. In 2003-2004, he is a member of the School of Social Science, Institute for Advanced Study, Einstein Drive, Princeton, New Jersey 08540, USA.e-mail:turner@ias.edu.
Just as most liberal democracies contain multiple religious traditions, contemporary societies are thoroughly 'multicultural.' Citizens identify themselves with numerous identity groups and cultural traditions. They are not all guided by the same set of ethical norms ${ }^{3}$. They do not all see particular policies or social practices as intuitively ethical or reasonable. Some individuals argue that ES cell research holds tremendous promise for the development of numerous new treatment modalities, whereas others argue for a ban on this research. And some individuals begin from the premise that gene therapy might ultimately provide a targeted, highly effective mode of treating various diseases, whereas others regard genetic engineering as the ultimate expression of technological hubris.

In multicultural, multifaith social orders, society cannot always be expected to reach a consensus in which everyone is guided by the same set of moral norms. With most matters of consequence, there will be dissenters who conclude that their most cherished moral norms are not guiding public policy and legislation.

'Consensus' is therefore a utopian fantasy. Any legal or policy decision will be declared by some social actors to represent a 'victory' for their moral agenda. Others will conclude that their views have been banished to the margins of ethical deliberation ${ }^{4}$. If we think that society must reach a full consensus before legislation is legitimated, we generate insurmountable roadblocks to policy making. The existence of a handful of dissenters means society has failed to reach a consensus. Inevitably, the argument one hears is that more democratic deliberation is required to accommodate these dissenters. Additional 'educational initiatives' are needed. Perhaps another town hall gathering, citizens' consensus panel or series of citizens' meetings will enable democratic deliberation to generate shared, common understandings $s^{5,6}$.

If we cannot expect society to reach a consensus because society consists of multiple social actors and is not constituted by a single mind, what goal ought we to set when crafting policies and legislation intended to regulate complex biomedical technologies? What we need, I suggest, is provided by the institutions already available in functioning liberal democracies. We need legislators able to hear the arguments and claims of concerned citizens. We need legislative assemblies with committees and investigative bodies. We need functioning courts capable of responding to difficult cases and critically assessing government policies and legislation. We need all the social mechanisms and feedback loops found in complex societies. However, these institutions are not mechanisms for inevitably achieving consensus or enabling society to reach a position of 'reflective equilibrium.' The social institutions of liberal democratic societies are not just engines for producing shared understandings. Courts and legislatures are valuable precisely because they are guided by norms permitting decisions to be reached even where disagreements exist ${ }^{7}$.

If we inhabited theocracies, rather than multicultural, multifaith societies, there would be less need for institutions capable of generating legislation, policies and regulations even where disagreements persist. However, many of us inhabit societies containing multiple cultural, philosophical and religious traditions. We should spend less time pining for the utopian ideal of society's reaching consensus about biomedical technologies. We should recognize that citizens and advocacy groups will generate different ethical analyses of such topics as ES cell research, therapeutic cloning and xenotransplantation.

Dissenters and critics of government policies need to be able to introduce their moral claims to public debate. Of equal importance, policies and legislation need to be crafted to regulate biomedical technologies even where social critics and dissenters are dissatisfied with 'official' government responses. It is usually better to have a generally adequate piece of legislation or public policy than forever wait for the day when society will finally reach consensus.

1. Engelhardt, H.T. Cambridge Q. Healthcare Ethics 11, 7-16 (2002)

2. Gutmann, A. \& Thompson, D. Hastings Cent. Rep. 27, 38-41 (1997).

3. Jensen, L.A. Hum. Dev. 40, 325-344 (1997).

4. Fish, S. in Deliberative Politics: Essays on Democracy and Disagreement (ed. Macedo, S.) 88-102 (Oxford University Press, Oxford, UK, 1999).

5. Abelson, J. et al. Soc. Sci. Med. 57, 239-251 (2003).

6. Leroux, T., Hirtle, M. \& Fortin, L.-N. J. Consum. Policy 21, 445-481 (1998).

7. Hampshire, S. Justice Is Conflict (Princeton University Press, Princeton, New Jersey, USA, 2000). 